\title{
Exopolysaccharides modify functional properties of whey protein concentrate
}

\author{
G. Deep, ${ }^{1}$ A. N. Hassan, ${ }^{2}$ and L. Metzger \\ Dairy Science Department, South Dakota State University, Brookings 57007
}

\begin{abstract}
The objective of this research was to produce whey protein concentrate (WPC) with modified functionality using exopolysaccharide- (EPS) producing cultures. Two different EPS-producing cultures, Lactococcus lactis ssp. cremoris JFR and Streptococcus thermophilus, producing EPS1 and EPS2 respectively, were used in this study. One EPS-nonproducing commercial cheese culture (DVS 850; Chr. Hansen, Milwaukee, WI) was used as the control. Reconstituted sweet whey powder was used in this study to eliminate variations from fresh whey. Cultures grown overnight in reconstituted WPC $(10 \% \mathrm{wt} / \mathrm{vol})$ were added, directly or after overnight cooling (cooled EPS), at 2\% (wt/vol) to $6 \%$ (wt/ wt) solution of reconstituted whey. Whey was then high-temperature, short-time pasteurized at $75^{\circ} \mathrm{C}$ for $35 \mathrm{~s}$ and ultrafiltered to a volume reduction factor of 5. Ultrafiltered whey (retentate) was spray dried at inlet and outlet air temperatures of 200 and $90^{\circ} \mathrm{C}$, respectively, to obtain WPC. In general, the solubility of WPC was higher at $\mathrm{pH} 7$ than at $\mathrm{pH} 3$. Whey protein concentrate containing EPS2 exhibited higher protein solubility than did WPC containing no EPS. Also, the presence of EPS in WPC decreased protein denaturation. The emulsifying ability of WPC containing EPS was higher than that in control. Addition of EPS to WPC significantly enhanced its gelling ability. Foam overrun and hydrophobicity of WPC were not affected by addition of EPS. In conclusion, data obtained from this study show that EPS modify WPC functionality. The extent of modification depends on the type of EPS. Cooling of culture containing EPS before its addition to whey further reduced WPC protein denaturation and increased its solubility at $\mathrm{pH} 7$ and gel hardness.
\end{abstract}

Key words: whey protein concentrate, denaturation, gelation, exopolysaccharide

\section{INTRODUCTION}

Whey is the serum fraction obtained during the manufacture of cheese by precipitating casein from

Received April 20, 2012.

Accepted June 22, 2012.

${ }^{1}$ Current address: Saputo Cheese USA Inc., Big Stone City, SD.

${ }^{2}$ Corresponding author: Ashraf.Hassan@sdstate.edu milk. Whey comprises about 80 to $90 \%$ of the volume of milk entering the cheesemaking process and contains about $50 \%$ of the solids and $20 \%$ of total proteins present in the original whole milk (Jelen, 2000). Whey can be fractionated using UF and spray dried to produce whey protein concentrate (WPC). Whey protein concentrates are widely used as ingredients in foods due to their exceptional nutritional and functional properties. The properties of WPC that are of interest to food manufacturers are gelation, solubility, water binding, emulsification, and foaming. Whey protein concentrates are used in a variety of products, such as frozen desserts, confectionaries, coffee whiteners, spreads, whipped foams, baked goods, and processed meats.

Modifications in functional properties of WPC can lead to wider applications. Various studies have been undertaken to modify functional properties of WPC, including changes in manufacturing parameters, and application of salts and polysaccharides (Mishra et al., 2001; Zhang and Foegeding, 2003; Zhu et al., 2008). Polysaccharides, such as pectin and carboxymethyl cellulose, form complexes with whey proteins and change their functional properties (Mishra et al., 2001). Factors affecting formation and stability of polysaccharidewhey protein complexes include $\mathrm{pH}$, ionic strength, charge density on proteins and polysaccharides, and processing conditions.

Exopolysaccharides (EPS) are high-molecular weight polymers, composed of sugar residues, produced by microorganisms outside their cell wall. Exopolysaccharide-producing cultures are widely used to improve the physical properties of reduced-fat cheeses (Hassan and Awad, 2005; Hassan, 2008). The released EPS in cheese whey may modify the functional properties of WPC. The objective of this study was to determine if EPS modify WPC functionality.

\section{MATERIALS AND METHODS}

\section{Whey Protein Source}

Sweet whey powder (Davisco Foods International Inc., Eden Prairie, MN) was used as the whey protein source. A single lot of whey powder was used for all replications to avoid possible variations in powder from different lots. 


\section{Cultures}

Three different cultures were used in the study: an EPS-producing culture of Lactococcus lactis ssp. cremoris JFR (University of Georgia, Athens; Purohit et al., 2009), an EPS-producing culture of Streptococcus thermophilus (ST-PH; isolated from retail yogurt; Purohit et al., 2009), and an EPS-nonproducing commercial cheese culture (DVS 850; Chr. Hansen, Milwaukee, WI) were used. The 2 EPS-producing cultures represented thermophilic and mesophilic lactic acid bacteria and produced different rheological properties in fermented milk (Purohit et al., 2009). Also, differences in structure of EPS produced by Strep. thermophilus and Lc. lactis ssp. cremoris have been reported (De Vuyst et al., 2001). Reconstituted (10\% wt/vol) WPC (34\% protein; Foremost Farms USA, Baraboo, WI) was used as a culturing medium. The incubation temperature was $30^{\circ} \mathrm{C}$ for Lc. lactis ssp. cremoris JFR and DVS 850, whereas it was $37^{\circ} \mathrm{C}$ for ST-PH. The final $\mathrm{pH}$ value of cultures was 4.6. One set of each of Lc. lactis ssp. cremoris JFR and ST-PH cultures grown in reconstituted WPC was kept overnight in a cooler at $4^{\circ} \mathrm{C}$ to obtain cooled EPS.

\section{Whey Powder Reconstitution}

Whey powder was reconstituted in water $(6 \% \mathrm{wt} /$ wt) at room temperature. Five batches of $150 \mathrm{~kg}$ of reconstituted whey were prepared. Reconstituted whey was kept in a cooler $\left(4^{\circ} \mathrm{C}\right)$ overnight to ensure proper hydration. The next day, 5 cultures were added (at $2 \%$, $\mathrm{wt} / \mathrm{wt}$ ) to separate batches of whey, resulting in 5 different treatments.

\section{WPC Manufacture}

Whey batches containing cultures were separately HTST pasteurized $\left(35 \mathrm{~s}\right.$ at $\left.75^{\circ} \mathrm{C}\right)$. Pasteurized whey was UF through a 10-KDa-molecular weight cut-off membrane of $5.6 \mathrm{~m}^{2}$ surface area (Koch Membrane Systems Inc., Wilmington, $\mathrm{MA}$ ) at $25^{\circ} \mathrm{C}$ to an approximate concentration factor of $5 \times$ by weight. All UF retentates were spray dried (ASO 412E Niro spray dryer; Niro Inc., Columbia, MD) separately. The inlet air temperature was maintained at $200^{\circ} \mathrm{C}$ and the outlet air temperature was $90^{\circ} \mathrm{C}$. Powders (WPC) were collected in 2 layers of self-locking plastic bags and stored at $4^{\circ} \mathrm{C}$. Three replications were done.

The following WPC powders were manufactured: (1) WPC containing no EPS, obtained from whey mixed with DVS-850 culture (control, WPC-CON), (2) WPC containing EPS, obtained from whey mixed with Lc. lactis ssp. cremoris JFR culture (WPC-EPS1), (3) WPC containing cooled EPS, obtained from whey mixed with overnight cooled Lc. lactis ssp. cremoris JFR culture (WPC-EPS1C), (4) WPC containing EPS, obtained from whey mixed with ST-PH culture (WPC-EPS2), and (5) WPC containing EPS, obtained from whey mixed with overnight cooled ST-PH culture (WPC-EPS2C).

\section{Compositional Analysis}

Powder samples were analyzed for moisture by drying in a vacuum oven at $100^{\circ} \mathrm{C}$ for $5 \mathrm{~h}$ (AOAC International, 2000; method 927.05). Fat content was determined by the AOAC International official method (AOAC International, 2000; method 932.06). Samples were ignited at $550^{\circ} \mathrm{C}$ in a muffle furnace to analyze for ash (AOAC International, 2000; method 930.30). Nitrogen content was determined by the micro-Kjeldahl method (Kjeltec 2200; Foss Analytical, Eden Prairie, MN), and protein content was determined by using a nitrogen conversion factor of 6.38 (AOAC International, 2000; method 960.52).

\section{Functional Properties}

Solubility, denaturation, emulsification ability, hydrophobicity, foam overrun, minimum gelling concentration, and gel strength of WPC were evaluated. All protein solutions were kept overnight at $4^{\circ} \mathrm{C}$ to hydrate.

Solubility. Solubility was determined by the method described by Morr (1985). About $500 \mathrm{mg}$ of WPC was weighed into a $150-\mathrm{mL}$ beaker and carefully dispersed by adding $40 \mathrm{~mL}$ of distilled water. After complete dispersion, $\mathrm{pH}$ was adjusted to 7.0 with $0.1 \mathrm{~N} \mathrm{HCl}$ or $\mathrm{NaOH}$. Solutions were kept overnight at $4^{\circ} \mathrm{C}$. The next day, the dispersion was transferred to a volumetric flask and made to $50 \mathrm{~mL}$ with distilled water. The dispersion was then centrifuged for $30 \mathrm{~min}$ at $20,000 \times g$ at $27 \pm 1^{\circ} \mathrm{C}$ and the protein content of the supernatant was determined by the micro-Kjeldahl method (AOAC International, 2000). Percent protein solubility was computed as the portion of total protein recovered in the supernatant fraction as follows:

$$
\% \text { Solubility }=\frac{\% \text { protein in supernatant }}{\% \text { total protein }} \times 100
$$

Denaturation. The method described by Moatsou et al. (2003) was used to determine the level of protein denaturation. Two-percent (wt/vol) protein solutions $(50 \mathrm{~mL})$ were prepared in a manner similar to that described for solubility. Total protein was determined by the micro-Kjeldahl method (AOAC International, 2000 ), using a nitrogen conversion factor of 6.38 . The $\mathrm{pH}$ of the solution was adjusted to 4.6 with $0.1 \mathrm{~N} \mathrm{HCl}$. 
Only native whey proteins remain soluble at this $\mathrm{pH}$. After filtration through Whatman filter paper no. 40 (Whatman International Ltd., Piscataway, NJ), the filtrate was analyzed for protein content. The level of protein denaturation was calculated from the following equation:

$$
\begin{gathered}
\% \text { Denaturation }= \\
\frac{\% \text { total protein }-\% \text { protein in filtrate }}{\% \text { total protein }} \times 100 .
\end{gathered}
$$

Emulsification Ability. The turbidimetric method of Casper et al. (1999), with slight modifications, was used to determine the emulsification ability. Twentyeight milliliters of $1 \%$ protein solution (wt/vol) in phosphate buffer ( $\mathrm{pH} 8.0$ ) and $12 \mathrm{~mL}$ of soybean oil (Pure Wesson; ConAgra Foods Inc., Omaha, NE) were emulsified using a hand-held mixer (Bio Homogenizer M 133/1281-0; Biospec Products Inc., Bartlesville, OK) for 4 min while cooling in an ice-water bath. The emulsion was diluted with $160 \mathrm{~mL}$ of phosphate buffer. A $0.02-\mathrm{mL}$ aliquot of this solution was added to $10 \mathrm{~mL}$ of phosphate buffer and turbidity was measured at a wavelength of $500 \mathrm{~nm}$ with a spectrophotometer. Absorbance values indicated the emulsifying ability.

Foam Overrun. The method described by Phillips et al. (1987) was used with some modifications for measuring the foam overrun. A $5 \%$ (wt/vol) protein solution $(75 \mathrm{~mL})$ adjusted to $\mathrm{pH} 7.0$ was carefully poured into a kitchen mixer bowl (Sunbeam Deluxe Mixmaster Mixer; Sunbeam Appliance Co., Downers Grove, IL) to avoid splashing and foaming. The protein dispersion was whipped at a mixer speed level of 12 (egg white) for $15 \mathrm{~min}$. Because the foam produced was not thick enough to measure overrun by weight, measurements were done by volume. After 15 min of whipping, foam was quickly transferred to a volumetric cylinder and the foam volume was measured. The volumetric cylinder was kept covered until all foam subsided (about $1 \mathrm{~h}$ ). The volume of the protein dispersion in the cylinder was measured after the foam subsided completely. Foaming capacity was recorded as foam overrun calculated from the following equation:

$$
\begin{gathered}
\text { Foaming capacity ( } \% \text { overrun })= \\
\frac{\text { foam volume }- \text { volume of protein dispersion }}{\text { volume of protein dispersion }} \times 100 \text {. }
\end{gathered}
$$

Gelation. Minimum gelation concentration was measured as least concentration endpoint, with some modifications to the method described by Brandenberg et al. (1992). Ten-percent (wt/vol) protein solutions adjusted to $\mathrm{pH} 7$ were allowed to hydrate 12 to $15 \mathrm{~h}$ in a refrigerator at $5^{\circ} \mathrm{C}$. Ten-milliliter protein solutions, ranging from 5 to $10 \%$ (wt/vol, $0.5 \%$ increment) concentration, were prepared in glass tubes using distilled water. Solutions were vortexed, covered with aluminum foil, and then placed in a water bath maintained at $80^{\circ} \mathrm{C}$ for $30 \mathrm{~min}$. Tubes were then placed under running tap water for $30 \mathrm{~min}$ and kept 12 to $15 \mathrm{~h}$ in the refrigerator at $5^{\circ} \mathrm{C}$, after which they were visually observed for gelation. Least concentration endpoint was defined as the lowest protein concentration that formed a stable, non-pourable gel when turning tubes upside down.

Gel hardness was also determined using a texture profile analyzer (TA.XTPlus texture analyzer; Texture Technologies Corp., Scarsdale, NY). Twelve-percent (wt/vol) protein solutions adjusted to $\mathrm{pH} 7$ were allowed to hydrate 12 to $15 \mathrm{~h}$ in a refrigerator at $5^{\circ} \mathrm{C}$. Gels were formed in beakers by placing in a water bath maintained at $80^{\circ} \mathrm{C}$ for $30 \mathrm{~min}$. After $30 \mathrm{~min}$, beakers were placed in running tap water bath for 30 min and kept 12 to $15 \mathrm{~h}$ in the refrigerator at $5^{\circ} \mathrm{C}$. Cylinders of 20-mm diameter were plugged out using cheese borers and cut to a height of $20 \mathrm{~mm}$. Hardness of WPC gels was measured at $40 \%$ compression level on gel cylinders using a load cell of $50 \mathrm{~kg}$ at crosshead speed of $50 \mathrm{~mm} /$ $\min$.

Hydrophobicity. Hydrophobicity was determined by the method described by Lee et al. (2006), with slight modifications. Whey protein concentrate powders were diluted to selected protein concentrations of 0.005 , $0.01,0.02$, and 0.03 in $0.1 \mathrm{M}$ phosphate buffer at $\mathrm{pH}$ 7. Thirty microliters of $8.0 \mathrm{mM}$ 1-anilino-naphthalene8-sulfonate (ANS) fluorescence probe was then added to $3 \mathrm{~mL}$ of each of the WPC preparations. Hydrophobic sites on the protein surface exhibiting affinity for the ANS fluorescence probe were measured at excitation and emission wavelengths of 390 and $470 \mathrm{~nm}$, respectively. Fluorescence intensity was determined with an Aminco-Bowman II Luminescence spectrometer (Thermo Electron Corp., Madison, WI). Net relative fluorescence intensity at each protein concentration was determined by subtracting the fluorescence intensity of the whey protein solution containing no ANS from the intensity of the corresponding whey protein solution containing ANS. The initial slope of the plot of relative fluorescence intensity versus protein concentration was calculated by linear regression analysis and designated the surface hydrophobicity index of WPC.

\section{Statistical Analysis}

Data for WPC represent the average of 3 replicates. The experiment of EPS addition after UF was done as a single trial. For each replicate, 2 measurements were used for computation. The GLM procedure from 
the SAS package (SAS Institute, 2006) was used for ANOVA. Means separation was conducted using Scheffe grouping. Differences were considered significant at $P<0.05$.

\section{RESULTS AND DISCUSSION}

\section{Chemical Composition}

The chemical composition of the WPC powders is shown in Table 1. Protein and moisture contents ranged from 30.9 to $31.3 \%$ and 3.3 to $3.5 \%$, respectively. The fat level was between 2.1 to $2.3 \%$ and ash content was in the range of 7.5 to $7.7 \%$. Five-volume reduction UF concentration is commercially used to obtain WPC 34 . The WPC produced in this study contained a lower protein level (32.14\% on a DM basis) than that found in commercial products. Results showed no significant differences $(P \geq 0.05)$ in protein, moisture, fat, and ash contents among treatments. Because the manufacturing process (except EPS addition) and the chemical composition of all treatments were the same, differences in the functionality, if any, of WPC were attributed to the added culture/EPS.

\section{Functionality of WPC}

Whey protein concentrates were tested for solubility, protein denaturation, emulsification ability, foam overrun, gel hardness, minimum gel concentration, and hydrophobicity. Exopolysaccharides produced by the 2 cultures used in this study affected the functional properties of WPC to different extents. Culture had a significant $(P<0.05)$ effect on solubility, denaturation, emulsification, and gel hardness (Table 2). Whey protein-EPS interactions depend on temperature, $\mathrm{pH}$, and medium composition (de Kruif and Tuinier, 1999; Ayala-Hernández et al., 2008). Generally, in a system containing proteins and polysaccharides, 3 interaction possibilities exist: (1) at low concentrations or noninteracting polysaccharides, the system is at equilibrium; (2) phase separation occurs due to thermodynamic incompatibility; or (3) coacervates form and precipitate in 1 phase (Schmitt et al., 1998; Tuinier et al., 2000). The molecular characteristics vary among EPS from different strains (Hassan et al., 2003) which would affect their interaction with whey proteins. This results in varying effects on functionality of whey proteins, as seen in the present study. Table 2 also shows that cooling of culture containing EPS before its addition to whey can affect EPS functionality in WPC. Cooling of EPS had a significant $(P<0.05)$ effect on WPC denaturation, solubility at $\mathrm{pH} 7$, and gel hardness. Exopolysaccharides produced by the same bacterium can differ in size, branching, and charge, depending on conditions of fermentation, including medium composition, temperature, and $\mathrm{pH}$ (Ayala-Hernández et al., 2008). Schmitt et al. (1998) suggested that the decrease in temperature favors interactions between 2 polymers. Thus, cooling might change the confirmation and hydration of EPS and EPS-EPS interactions, which eventually affect EPS-protein interactions and functionality of WPC containing EPS.

Protein Solubility. The solubility analysis results of the WPC powders are shown in Table 3. Solubility of WPC was greater $(P<0.05)$ at $\mathrm{pH} 7$ than at $\mathrm{pH} 3$, which is consistent with the data reported by Pelegrine and Gasparetto (2005). Whey proteins form complexes with EPS. Such complexes are soluble at high $\mathrm{pH}$, with phase separation occurring below certain $\mathrm{pH}$ values (Weinbreck et al., 2003). Thus, lower solubility at pH 3 could be due to precipitation of whey protein-EPS complexes, which seem to be more soluble at higher $\mathrm{pH}$ values. Also, denatured whey proteins precipitate at $\mathrm{pH}$ 4.6 and some of these precipitates may not solubilize again when $\mathrm{pH}$ is further lowered to 3 .

At $\mathrm{pH}$ 7, WPC-EPS2 showed more solubility than WPC-CON (Table 3). Solubility of WPC-EPS1 was similar $(P \geq 0.05)$ to that of WPC-CON. No significant differences $(P \geq 0.05)$ in solubility were observed among treatments at $\mathrm{pH}$ 3.Various studies have shown that EPS interact with whey proteins (Ye, 2008). Addition of EPS to WPC solution resulted in increased viscosity, suggesting potential interaction between WPC and EPS (Briczinski and Roberts, 2002). Complexing proteins with anionic polysaccharides was reported to increase the solubility of proteins and inhibit protein

Table 1. Chemical composition of whey protein concentrates (WPC) made with and without exopolysaccharide (EPS) addition ${ }^{1}$

\begin{tabular}{lcccc}
\hline & \multicolumn{4}{c}{ Constituent (\%) } \\
\cline { 2 - 5 } Treatment $^{2}$ & Protein & Moisture & Fat & Ash \\
\hline WPC-CON & 31.2 & 3.3 & 2.1 & 7.7 \\
WPC-EPS1 & 30.9 & 3.3 & 2.2 & 7.8 \\
WPC-EPS1C & 31.3 & 3.4 & 2.2 & 7.7 \\
WPC-EPS2 & 31.3 & 3.3 & 2.2 & 7.5 \\
WPC-EPS2C & 30.9 & 3.5 & 2.3 & 7.7 \\
\hline
\end{tabular}

${ }^{1}$ Data represent averages of 3 replications, with each replication consisting of 2 measurements. Means in the same column without superscripts are not significantly different $(P \geq 0.05)$.

${ }^{2} \mathrm{WPC}-\mathrm{CON}=\mathrm{WPC}$ containing no EPS (control), obtained from whey mixed with DVS-850 culture (Chr. Hansen, Milwaukee, WI); WPC-EPS1 = WPC containing EPS, obtained from whey mixed with Lactococcus lactis ssp. cremoris JFR culture; WPC-EPS1C = WPC containing cooled EPS, obtained from whey mixed with overnight cooled Lactococcus lactis ssp. cremoris JFR culture; WPC-EPS2 = WPC containing EPS, obtained from whey mixed with Streptococcus thermophilus (ST-PH) culture; WPC-EP2C = WPC containing EPS, obtained from whey mixed with overnight cooled ST-PH culture. 
Table 2. Mean square and $P$-values (in parentheses) for functional properties of whey protein concentrates $\left(\right.$ WPC) ${ }^{1}$

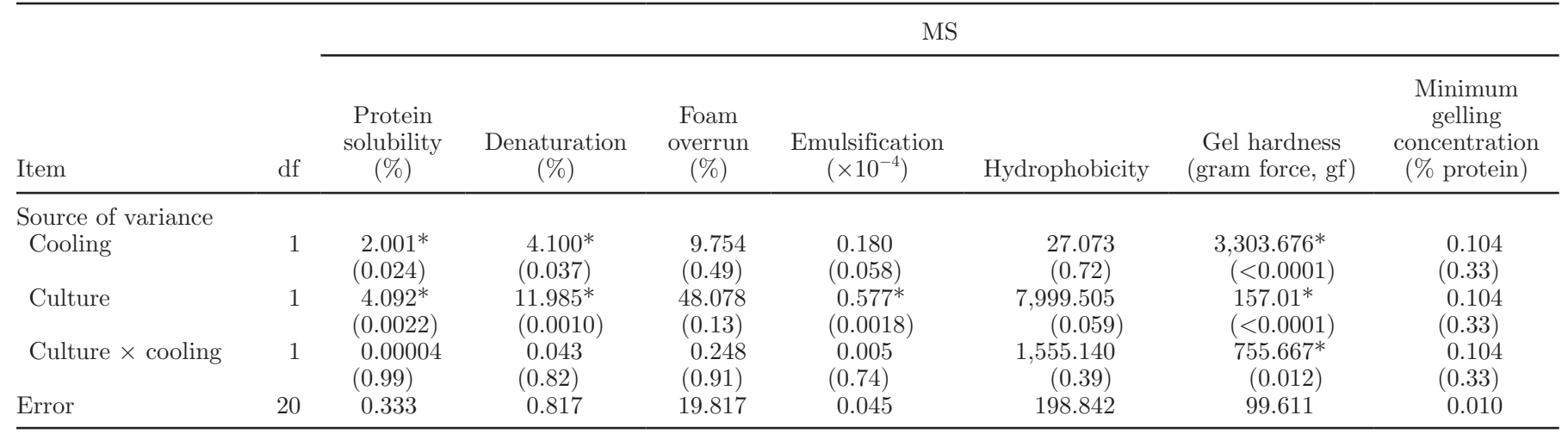

${ }^{1}$ Data represent averages of 3 replications, with each replication consisting of 2 measurements.

$* P<0.05$.

precipitation at their isoelectric point (Ye, 2008). Thus, in WPC solution containing EPS, a possibility exists of EPS-whey protein interactions. Such interactions may prevent protein precipitation. The lack of differences $(P \geq 0.05)$ in solubility among treatments at $\mathrm{pH}$ 3 may indicate that whey protein-EPS interactions and the possible formation of soluble whey protein-EPS complexes are $\mathrm{pH}$ dependent. Ayala-Hernández et al. (2008) reported that EPS-whey protein interactions depend on $\mathrm{pH}$, and suggested that negatively charged EPS (from Lc. lactis ssp. cremoris JFR) interact with positively charged sites on whey proteins at $\mathrm{pH}$ values around 5.5 to 5.8 .

Table 3. Whey protein solubility and denaturation in whey protein concentrates (WPC) made with and without exopolysaccharide (EPS) addition $^{1}$

\begin{tabular}{|c|c|c|c|}
\hline \multirow[b]{2}{*}{ Treatment $^{2}$} & \multicolumn{2}{|c|}{$\begin{array}{c}\text { Solubility } \\
\text { (\% soluble protein) }\end{array}$} & \multirow{2}{*}{$\begin{array}{c}\text { Denaturation } \\
\text { (\% denatured } \\
\text { protein) }\end{array}$} \\
\hline & pH 3 & pH 7 & \\
\hline WPC-CON & $89.4^{\mathrm{a}, \mathrm{A}}$ & $89.9^{\mathrm{a}, \mathrm{B}}$ & $8.0^{\mathrm{a}}$ \\
\hline WPC-EPS1 & $89.7^{\mathrm{a}, \mathrm{A}}$ & $90.5^{\mathrm{ab}, \mathrm{B}}$ & $5.3^{\mathrm{b}}$ \\
\hline WPC-EPS1C & $89.8^{\mathrm{a}, \mathrm{A}}$ & $91.1^{\mathrm{bc}, \mathrm{B}}$ & $4.4^{\mathrm{bc}}$ \\
\hline WPC-EPS2 & $89.7^{\mathrm{a}, \mathrm{A}}$ & $91.3^{\mathrm{bc}, \mathrm{B}}$ & $3.8^{\mathrm{bc}}$ \\
\hline WPC-EPS2C & $90.0^{\mathrm{a}, \mathrm{A}}$ & $91.9^{\mathrm{c}, \mathrm{B}}$ & $3.0^{\mathrm{c}}$ \\
\hline
\end{tabular}

\footnotetext{
${ }^{\mathrm{a}-\mathrm{c}}$ Means within a column without common lowercase superscripts are significantly different $(P<0.05)$.

${ }^{\mathrm{A}, \mathrm{B}}$ Means within a row without common uppercase superscripts are significantly different $(P<0.05)$.

${ }^{1}$ Data represent averages of 3 replications, with each replication consisting of 2 measurements.

${ }^{2}$ WPC-CON = WPC containing no EPS (control), obtained from whey mixed with DVS-850 culture (Chr. Hansen, Milwaukee, WI); WPC-EPS1 = WPC containing EPS, obtained from whey mixed with Lactococcus lactis ssp. cremoris JFR culture; WPC-EPS1C = WPC containing cooled EPS, obtained from whey mixed with overnight cooled Lactococcus lactis ssp. cremoris JFR culture; WPC-EPS2 = WPC containing EPS, obtained from whey mixed with Streptococcus thermophilus (ST-PH) culture; WPC-EPS2C = WPC containing EPS, obtained from whey mixed with overnight cooled ST-PH culture.
}

Level of Protein Denaturation. Protein denaturation results were the inverse of solubility values. Whey protein concentrates containing EPS showed a significant decrease $(P<0.05)$ in protein denaturation (Table 3 ). Denatured whey protein in WPC containing no EPS was $8.0 \%$ of total protein, whereas it was only 5.3 to $3.0 \%$ in the presence of EPS. The protective effect of polysaccharides (not EPS) against protein denaturation has been reported (Zhang and Foegeding, 2003; Zhu et al., 2008; Vardhanabhuti et al., 2009). Various polysaccharides, such as dextran sulfate and $\lambda$-carrageenan, lowered the degree of heat-induced aggregation in whey proteins by forming protein-polysaccharide complexes (Zhang and Foegeding, 2003; Zhu et al., 2008; Vardhanabhuti et al., 2009). Whey proteins interact and form complexes with EPS (Ayala-Hernández et al., 2008). Such complexes could be responsible for whey protein stabilization and lower protein denaturation levels observed in the current study.

Emulsification Ability. Surface properties, similar to emulsification, require good solubilization and partial denaturation of proteins, which aid in structural flexibility and unfolding of the proteins at the interfacial layers, thereby stabilizing the 2-phase system (oilin-water emulsions). Results of the emulsifying ability analysis of the WPC powders are shown in Table 4. Addition of EPS increased the emulsification capacity of WPC $(P<0.05)$. The emulsifying ability index was 0.073 for WPC containing no EPS, whereas it ranged from 0.080 to 0.085 in the presence of EPS. The stabilization of protein emulsions increases by formation of ionic or covalent protein-polysaccharide complexes. This stabilization is dependent on the structural characteristics of polysaccharides (Schmitt et al., 1998). Emulsification properties of WPC were enhanced in the presence of pectin (Mishra et al., 2001). Thus, the higher emulsification index obtained in the current study 
for WPS containing EPS could also be attributed to whey protein-EPS interactions. In addition, the presence of EPS resulted in better solubility, which could be one of the possible reasons for the improvement in emulsification.

Foam Overrun. Foam overrun data are shown in Table 4. Whey protein concentrates did not produce stable foams, and foam overrun was not appreciable. No significant differences $(P \geq 0.05)$ were observed among treatments in foam overrun results, which ranged from 70.6 to $74.7 \%$. The mechanism of foam formation by WPC is similar to that of emulsification, which includes partial unfolding of protein structure at the liquid-gas interface and formation of a film around air bubbles, thus stabilizing the foam. Some differences were observed among treatments in emulsification properties. Therefore, differences in foam overrun were expected. However, due to the low magnitude of overrun values, the differences were found not to be statistically significant $(P>0.05)$.

Gelling Properties. Data in Table 5 indicate that EPS assist in the formation of a protein gel matrix. Exopolysaccharides increased $(P<0.05)$ WPC gel hardness (Table 5). The gel hardness of WPC-CON was 295 gram force (gf), whereas it ranged from 325 to 398 gf in WPC containing EPS. Also, the minimum gelling concentration decreased $(P<0.05)$ with addition of EPS. Whey protein concentrates with no EPS had minimum gelling concentration of $7.08 \%$, whereas it was 6.5 to $6.75 \%$ in WPC containing EPS. Addition of EPS2 affected gel strength to a greater extent, producing harder gels as compared with EPS1. The hard-

Table 4. Emulsifying ability and foam overrun of whey protein concentrates (WPC) made with and without exopolysaccharide (EPS) $\operatorname{addition}^{1}$

\begin{tabular}{|c|c|c|}
\hline Treatment $^{2}$ & $\begin{array}{c}\text { Emulsifying ability } \\
\text { (absorbance at } \\
500 \mathrm{~nm} \text { ) }\end{array}$ & $\begin{array}{c}\text { Foam } \\
\text { overrun (\%) }\end{array}$ \\
\hline WPC-CON & $0.073^{\mathrm{a}}$ & $71.7^{\mathrm{a}}$ \\
\hline WPC-EPS1 & $0.080^{\mathrm{b}}$ & $73.7^{\mathrm{a}}$ \\
\hline WPC-EPS1C & $0.082^{\mathrm{bc}}$ & $74.7^{\mathrm{a}}$ \\
\hline WPC-EPS2 & $0.083^{\mathrm{bc}}$ & $70.6^{\mathrm{a}}$ \\
\hline WPC-EPS2C & $0.085^{\mathrm{c}}$ & $72.1^{\mathrm{a}}$ \\
\hline
\end{tabular}

\footnotetext{
${ }^{\mathrm{a}-\mathrm{c}}$ Means within a column without common superscripts are significantly different $(P<0.05)$.

${ }^{1}$ Data represent averages of 3 replications, with each replication consisting of 2 measurements.

${ }^{2}$ WPC-CON = WPC containing no EPS (control), obtained from whey mixed with DVS-850 culture (Chr. Hansen, Milwaukee, WI); WPC-EPS1 $=$ WPC containing EPS, obtained from whey mixed with Lactococcus lactis ssp. cremoris JFR culture; WPC-EPS1C = WPC containing cooled EPS, obtained from whey mixed with overnight cooled Lactococcus lactis ssp. cremoris JFR culture; WPC-EPS2 = WPC containing EPS, obtained from whey mixed with Streptococcus thermophilus (ST-PH) culture; WPC-EPS2C = WPC containing EPS, obtained from whey mixed with overnight cooled ST-PH culture.
}

ness of WPC containing EPS2 gels ranged from 387 to 398 gf, whereas it was between 325 to 359 gf in samples containing EPS1. Whey protein gels are formed by partial denaturation and aggregation of protein molecules. Tavares and da Silva (2003) suggested that under neutral $\mathrm{pH}$, protein network forms a continuous phase that accommodates the polysaccharide chains, which act as a filler. This would lower the critical concentration to gel and increase gel rigidity. Exopolysaccharides can also act in the same manner to increase gel hardness. The effect of both EPS1 and EPS2 on the rheological properties of milk gels has been studied in our laboratory (Purohit et al., 2009). Elastic, viscous, and complex moduli were much greater in milk fermented with the EPS2-producing culture than in that fermented with the EPS1-producing culture, indicating firmer gel (Purohit et al., 2009). This may explain the harder gel in WPC-EPS2 than in WPC-EPS1. However, the water-holding capability and consistency coefficient of EPS1 were higher than those in EPS 2 (Purohit et al., 2009). This may have affected the EPS-water phase interaction during cooling to a greater extent in EPS1 than in EPS2, leading to improved gel hardness in WPC-EPS1C.

Hydrophobicity. Results for hydrophobicity analysis of whey protein concentrates are depicted in Table 5. No significant differences $(P \geq 0.05)$ were observed among treatments, with hydrophobicity index ranging from 331 to 339. Differences were observed in solubility, emulsification, denaturation and gelling properties, indicating that EPS form complexes with whey proteins, which affected their functionality. This modification in functionality may result from changes in the extent of the exposure of their hydrophobic residues on the surface of the protein molecules. Therefore, some differences in hydrophobicity values were expected. However, the differences produced, if any, seemed to be too small in magnitude to be measured by the method used in this study.

\section{CONCLUSIONS}

Whey protein concentrate containing EPS exhibited enhanced functional properties. The effect of EPS was dependent on its type and cooling before its addition. The most interesting finding of this research was the effect of EPS on gelation of WPC. Although statistically significant, the practical importance of modifications in other functional properties such as solubility and emulsification needs further investigation. Future research will be directed toward understanding the role of EPS structures and their interactions with whey proteins on WPC characteristics. 
Table 5. Gelling properties and hydrophobicity of whey protein concentrates (WPC) made with and without exopolysaccharide (EPS) addition ${ }^{1}$

\begin{tabular}{lccc}
\hline Treatment $^{2}$ & $\begin{array}{c}\text { Gelling concentration } \\
(\% \text { protein) }\end{array}$ & $\begin{array}{c}\text { Gel hardness } \\
\text { (gram force, gf) }\end{array}$ & $\begin{array}{c}\text { Hydrophobicity } \\
\text { index }\end{array}$ \\
\hline WPC-CON & $7.08^{\mathrm{a}}$ & $295^{\mathrm{a}}$ & $335^{\mathrm{a}}$ \\
WPC-EPS1 & $6.75^{\mathrm{b}}$ & $325^{\mathrm{b}}$ & $337^{\mathrm{a}}$ \\
WPC-EPS1C & $6.50^{\mathrm{b}}$ & $359^{\mathrm{c}}$ & $339^{\mathrm{a}}$ \\
WPC-EPS2 & $6.50^{\mathrm{b}}$ & $387^{\mathrm{d}}$ & $331^{\mathrm{a}}$ \\
WPC-EPS2C & $6.50^{\mathrm{b}}$ & $398^{\mathrm{d}}$ & $334^{\mathrm{a}}$ \\
\hline
\end{tabular}

${ }^{\mathrm{a}-\mathrm{d}}$ Means within the same column without common superscripts are significantly different $(P<0.05)$.

${ }^{1}$ Data represent averages of 3 replications, with each replication consisting of 2 measurements.

${ }^{2}$ WPC-CON $=$ WPC containing no EPS (control), obtained from whey mixed with DVS-850 culture (Chr. Hansen, Milwaukee, WI); WPC-EPS1 = WPC containing EPS, obtained from whey mixed with Lactococcus lactis ssp. cremoris JFR culture; WPC-EPS1C = WPC containing cooled EPS, obtained from whey mixed with overnight cooled Lactococcus lactis ssp. cremoris JFR culture; WPC-EPS2 = WPC containing EPS, obtained from whey mixed with Streptococcus thermophilus (ST-PH) culture; WPC-EPS2C = WPC containing EPS, obtained from whey mixed with overnight cooled ST-PH culture.

\section{ACKNOWLEDGMENTS}

We thank Dairy Management Inc. (Rosemont, IL) as administered by Dairy Research Institute for their financial support.

\section{REFERENCES}

AOAC International. 2000. Official Methods of Analysis. 17th ed AOAC International Gaithersburg, MD.

Ayala-Hernández, I., A. Hassan, H. D. Goff, R. Mira de Orduña, and M. Corredig. 2008. Production, isolation and characterization of exopolysaccharides produced by Lactococcus lactis ssp. cremoris JFR 1 and their interaction with milk proteins: Effect of $\mathrm{pH}$ and media composition. Int. Dairy J. 18:1109-1118.

Brandenberg, A. H., C. V. Morr, and C. L. Weller. 1992. Gelation of commercial whey protein concentrates: Effect of low molecular weight component. J. Food Sci. 57:427-432.

Briczinski, E. P., and R. F. Roberts. 2002. Production of an exopolysaccharide-containing whey protein concentrate by fermentation of whey. J. Dairy Sci. 85:3189-3197.

Casper, J. L., W. L. Wendorff, and D. L. Thomas. 1999. Functional properties of whey protein concentrates from caprine and ovine specialty cheese wheys. J. Dairy Sci. 82:265-271.

de Kruif, K. G., and R. Tuinier. 1999. Whey protein aggregates and their interaction with exo-polysaccharides. Int. J. Food Sci. Technol. 34:487-492.

De Vuyst, L., F. De Vin, F. Vaningelgem, and B. Degeest. 2001. Recent developments in the biosynthesis and applications of heteropolysaccharides from lactic acid bacteria. Int. Dairy J. 11:687-707.

Hassan, A. N. 2008. ADSA Foundation Scholar Award: Possibilities and challenges of exopolysaccharide-producing lactic cultures in dairy foods. J. Dairy Sci. 91:1282-1298.

Hassan, A. N., and S. Awad. 2005. Application of exopolysaccharideproducing cultures in reduced-fat Cheddar cheese. Cryo-scanning electron microscopy observations. J. Dairy Sci. 88:4214-4220.

Hassan, A. N., R. Ipsen, T. Janzen, and K. B. Qvist. 2003. Microstructure and rheology of yogurt made with cultures differing only in their ability to produce exopolysaccharides. J. Dairy Sci. 86:1632-1638.

Jelen, P. 2000. Whey: Composition, properties, processing, and uses. Pages: 2652-2661 in Wiley Encyclopedia of Food Science and Technology. 2nd ed. F. J. Francis, ed. Wiley, New York, NY.

Lee, W., S. Clark, and B. G. Swanson. 2006. Functional properties of high hydrostatic pressure treated whey protein. J. Food Process. Preserv. 30:488-501.
Mishra, S., B. Mann, and V. K. Joshi. 2001. Functional improvement of whey protein concentrate on interaction with pectin. Food $\mathrm{Hy}-$ drocoll. 15:9-15.

Moatsou, G., A. Hatzinaki, I. Kandarakis, and E. Anifantakis. 2003. Nitrogenous fractions during manufacture of whey protein concentrates from Feta cheese whey. Food Chem. 81:209-217.

Morr, C. V. 1985. Composition, physiochemical and functional properties of reference whey protein concentrates. J. Food Sci. 50:14061411.

Pelegrine, D. H. G., and C. A. Gasparetto. 2005. Whey proteins solubility as function of temperature and $\mathrm{pH}$. Lebenson. Wiss. Technol. 38:77-80.

Phillips, L. G., Z. Haque, and J. E. Kinsella. 1987. A method for the measurement of foam formation and stability. J. Food Sci 54:1074-1077.

Purohit, D. H., A. N. Hassan, E. Bhatia, X. Zhang, and C. Dwivedi. 2009. Rheological, sensorial, and chemopreventive properties of milk fermented with exopolysaccharide-producing lactic cultures. J. Dairy Sci. 92:847-856.

SAS Institute. 2006. User's Guide: Statistics. Version 9.1 ed. SAS Inst. Inc., Cary, NC.

Schmitt, C., C. Sanchez, S. Desobry-Banon, and J. Hardy. 1998. Structure and technofunctional properties of protein-polysaccharide complexes: A review. Crit. Rev. Food Sci. Nutr. 38:689-753.

Tavares, C., and J. A. Lopes da Silva. 2003. Rheology of galactomannan-whey protein mixed systems. Int. Dairy J. 13:699-706.

Tuinier, R., J. K. G. Dhont, and C. G. de Kruif. 2000. Depletioninduced phase separation of aggregated whey protein colloids by an exocellular polysaccharide. Langmuir 16:1497-1507.

Vardhanabhuti, B., U. Yucel, J. N. Coupland, and E. A. Foegeding. 2009. Interactions between $\beta$-lactoglobulin and dextran sulfate at near neutral $\mathrm{pH}$ and their effect on thermal stability. Food Hydrocoll. 23:1511-1520.

Weinbreck, F., H. Nieuwenhuijse, G. W. Robijn, and C. G. de Kruif. 2003. Complex formation of whey protein-exocellular polysaccharide EPS B40. Langmuir 19:9404-9410.

Ye, A. 2008. Complexation between milk proteins and polysaccharides via electrostatic interaction: Principles and applications- A review. Int. J. Food Sci. Technol. 43:406-415.

Zhang, G., and E. A. Foegeding. 2003. Heat-induced phase behavior of $\beta$-lactoglobulin/polysaccharide mixtures. Food Hydrocoll. 17:785-792.

Zhu, D., S. Damodaran, and J. A. Lucey. 2008. Formation of whey protein isolate (WPI)-dextran conjugates in aqueous solutions. J. Agric. Food Chem. 56:7113-7118. 